\title{
ADAM PRZYBECKI \\ Od cura animarum do cura pastoralis. Wokół wątpliwości terminologicznych
}

Przed siedmiu laty, na łamach „Teologii Praktycznej”, opublikowany został artykuł pt. Duszpasterstwo. Watpliwości terminologiczne ${ }^{1}$. Jego autor pragnął przedstawić racje przemawiające za tym, żeby termin »duszpasterstwo «astapić terminem »wychowanie» albo »pedagogia" Kościoła i konsekwentnie - termin »teologia pastoralna" terminem »teologia pedagogii Kościoła ${ }^{2}$. Zwracał uwagę, że do dyskusji na ten temat skłoniło go kilka publikacji. Punkt wyjścia stanowił cytat z artykułu Piotra Sikory, który podnosił problem modelu Kościoła, odwołującego się do metafor „pasterza” i „owiec”, pochodzących z początków chrześcijaństwa. Nie chodziło mu jednak o kwestię samego pojęcia „duszpasterstwo”, ale o sugerowaną przez te metafory „ojcowsko-pasterską” wizję kościelnych struktur. W dalszej części swych rozważań, P. Sikora odwołując się do doświadczeń Kościoła pierwotnego, twierdził: Nasz Mistrz nakreślit wizję wspólnoty równych braci $i$ sióstr, $w$ której wszyscy maja świadomość, że sa dziećmi i uczniami - jedynym i bezpośrednim Nauczycielem i Mistrzem prowadzacym wszystkich do wspólnego Ojca jest Chrystus ${ }^{3}$.

Kolejny cytat pochodził z rozmowy, jaką z Abbé Pierre'em (Henri Grouès'em) przeprowadził Cezary Lewanowicz. Znany francuski duszpasterz ubogich i bezdomnych, założyciel wspólnoty Emaus, stwierdził: $w$ Kościele trzeba by zmienić wiele rzeczy, poczawszy od języka. Powiedziałem kiedyś Janowi Pawtowi II: Ojcze używasz zwrotów »owieczki«, »dobry pasterz" ... Te metafory nie

Adam P R Z Y B E C K I, ks. prof. dr hab., kierownik Zakładu Teologii Pastoralnej, Wydział Teologiczny UAM, Poznań, e-mail: adamfran@amu.edu.pl

${ }^{1}$ R. N i parko: Duszpasterstwo. Wątpliwości terminologiczne. „Teologia Praktyczna”. T. 8: 2007 s. 283-289 [artykuł dostępny także na str.: www.teologiapraktyczna.amu.edu.pl].

${ }^{2}$ Tamże, s. 283.

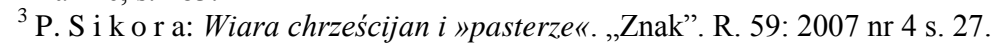


przemawiaja już do wspótczesnego człowieka. One były wymowne w Izraelu $w$ czasach Chrystusa, bo byt to lud pasterski. Ale dla nas, mieszkańców betonowych miast, one nic nie znacza ${ }^{4}$.

Dla autora artykułu, pomieszczonego we wspomnianym czasopiśmie „Teologia Praktyczna", przytoczone wypowiedzi bez watpliwości zwracaja uwage na potrzebę zastapienia tej terminologii, tworzonej od czasownika "paść« oraz rzeczowników »pasterz" $i$ »owczarnia«. Chodzi tu zwlaszcza o termin »duszpasterstwo «, którym przyjęło się określać działalność Kościoła, a także »duszpasterz" na określenie przedstawiciela hierarchii kościelnej, przede wszystkim biskupów $i$ kaptanów. W konsekwencji należałoby zmienić określenia dziedziny wiedzy teologicznej zajmujacej się nad działalnościa Kościoła, dotąd nazywanej »teologia pastoralna« lub »teologia praktyczna»"

Zgłoszone uwagi skłaniają do podjęcia, skądinąd bardzo ciekawej dyskusji, która - jak wspomniano w cytowanym artykule - trwa w Polsce od dłuższego czasu. Przedstawimy zatem problem kształtowania się samego pojęcia, następnie jego zależność od koncepcji teologii pastoralnej, by na koniec rozważyć możliwe rozwiązania z uwzględnieniem pojawiających się propozycji.

\section{Kwestia pojęcia}

Nie sposób podważyć stwierdzenie, że termin „duszpasterstwo" nawiązuje do biblijnych obrazów pasterza i owczarni. Podkreśla on, zgodnie z ewangelijnym przekazem (J 10,1-16), przede wszystkim postawę Chrystusa wobec uczniów i całego Kościoła. Od czasów apostolskich posługę biskupów i prezbiterów wobec powierzonego im Kościoła rozumiano i określano jako troskę pasterzy (por. Dz 20,28-30; 1 P 5,1-5). Sam termin „duszpasterstwo” zadomowił się mocno w Kościele i przetrwał do dzisiaj, choć biblijne odniesienie kształtowało do niedawna jego interpretację głównie klerykalistyczną, która akcentowała wyłącznie działalność hierarchii. Poza tym etymologiczna interpretacja wspomnianego terminu sugeruje, sprowadzenie przedmiotu działalności zbawczej Kościoła jedynie do ludzkiej duszy. Może to rodzić fałszywe przekonanie, że duszpasterstwo nie obejmuje całego człowieka, zarówno w jego wymiarze indywidualnym jak i społecznym ${ }^{6}$.

Od połowy XX w. pojawiają się próby znalezienia określenia, które oderwałoby określenie „duszpasterstwo” od niezbyt czytelnej dla współczesnego człowieka symboliki nomadyczno-rolniczej. W związku z tym - szczególnie w teo-

${ }^{4}$ Kościól wolny od przywilejów. Z Abbé Pi e rre'em rozmawia C e zary Le wanowi c z. „Znak”. R. 59: 2007 nr 4 s. 102.

${ }^{5} \mathrm{R}$. N i p a r k o: Duszpasterstwo. Watpliwości terminologiczne, dz. cyt., s. 284.

${ }^{6}$ Por. R. K a m iń s k i, W. P r z y g o d a: Duszpasterstwo. W: Leksykon teologii pastoralnej. Red. R. K a miń ski, W. Pr z y g od a, M. F i ałk o w s ki. Lublin 2006 s. 201. 
logii niemieckiej - proponowano nowe określenia, które jednak nie zastąpiły dotychczasowego pojęcia, ale stały się jego synonimami. Pośród nich pojawiły się takie, jak: pośrednictwo zbawcze (Heilsvermittlung), posługa zbawienia (Heilsdienst), posługa Kościoła (Kirchdienst), troska o ludzi (Menschensorge), samourzeczywistnianie się Kościoła (Selbstverwirklichung der Kirche), samowypełnianie się Kościoła (Selbstvollzug der Kirche), samobudowanie się Kościoła (Selbsterbaung der Kirche) itp. Próbowano także wspomniane dylematy rozwiązać poprzez dookreślenie terminu „duszpasterstwo”, uzupełniając je różnymi przymiotniki, np. duszpasterstwo środowiskowe (Milieupastoral), duszpasterstwo misyjne (Missionsseelsorge), duszpasterstwo zintegrowane (integrierte Seelsorge), duszpasterstwo kooperatywne (kooperative Seelsorge), duszpasterstwo służebne (diakonische Seelsorge), duszpasterstwo terapeutyczne (therapeutische Seelsorge $)^{7}$.

Te ostatnie rozwiązania w mijających latach funkcjonowania Kościoła lokalnego w nowej rzeczywistości społeczno-politycznej, zaowocowały w Polsce niezbyt szczęśliwymi propozycjami, które przyozdabiały każdy niemal aspekt aktywności duszpasterskiej kolejnym przymiotnikiem. Prowadziło to niekiedy do tworzenia nieprecyzyjnych określeń, sprowadzających oczywiste pojęcia do granic absurdu i powodując ich rozmywanie. Wymownym tego przykładem było wprowadzenie do teologicznego języka, obiegowego określenia „duszpasterstwo katechetyczne” czy „duszpasterstwo liturgiczne”, które pewne specyficzne aspekty działalności duszpasterskiej Kościoła, stanowiące elementy składowe szerszego terminu „duszpasterstwo”, wyłączały z jego zakresu czyniąc odrębnymi pojęciami ${ }^{8}$.

Niezależnie od podejmowanych prób znalezienia bardziej czytelnego dla współczesnych określenia tego, co ma wyrażać termin „duszpasterstwo” oraz propozycji zastąpienia go bardziej adekwatnym mianem, wydaje się, że pozostaje on ciągle pojęciem opisującym rzeczywistość, którą ucieleśnia. Mimo zmieniających się koncepcji duszpasterstwa i nowych jego definicji, jest ciągle powszechnie rozpoznawalnym terminem, stosowanym na określenie posługi pośrednictwa zbawczego Kościoła, która charakteryzuje jego całą działalność. Rozumienie tego, czym jest duszpasterstwo - jak pokazuje historia - pozostawało zawsze i pozostaje nadal $\mathrm{w}$ ścisłym związku $\mathrm{z}$ funkcjonującą $\mathrm{w}$ danym okresie koncepcją teologii pastoralnej.

\footnotetext{
${ }^{7}$ Tamże. Por. także - P. M ü 11 e r: Seelsorge. W: Lexikon für die Theologie und Kirche. T. 9. Sonderausgabe 2006. Freiburg im Br. 2000, 2006 kol. 383-387.

${ }^{8}$ Zob. A. P r z y b e c k i: Duszpasterstwo katechetyczne czy pastoralne aspekty katechizacji? Próba uporządkowania pojęć. „Warszawskie Studia Pastoralne”. R. 2006 nr 3 s.186-196.
} 


\section{Od koncepcji teologii pastoralnej do koncepcji duszpasterstwa}

Powodem funkcjonowania nadal w praktyce teologiczno-kanonicznej terminu „duszpasterstwo”, mimo wspomnianych wcześniej słabości, jest - jak się wydaje - reinterpretacja jego koncepcji, dokonywana w procesie historycznego kształtowania się kolejnych wizji teologii pastoralnej. Nie ulega bowiem wątpliwości, że wizja duszpasterstwa pozostaje w ścisłym związku $\mathrm{z}$ funkcjonującą koncepcją teologii pastoralnej. Ta zależność kształtowała raczej samo rozumienie tego, czym jest duszpasterstwo, odsuwając na dalszy plan kwestie związane z poszukiwaniem adekwatnego określenia rzeczywistości, którą ono wyraża.

W chwili pojawienia się teologii pastoralnej jako odrębnej dyscypliny akademickiej w związku z powołaniem w 1777 r. na Wydziale Teologicznym Uniwersytetu Wiedeńskiego pierwszej katedry teologii pastoralnej, Stefan Rautenstrauch jej zadanie określał jako związane w całość przedstawienie wszystkich obowiązków duszpasterskich i sposobu ich wypełniania, traktując duszpasterza (duchownego) jako nauczyciela, pośrednika i zwierzchnika, którego związek z Kościołem nie był praktycznie dostrzegany. Liczyła się tylko aktywność poszczególnego duchownego, którego obowiązki miały ostatecznie charakter cywilno-państwowy. Takie widzenie sprawy kształtowało w oczywisty sposób rozumienie duszpasterstwa ${ }^{9}$.

W późniejszym okresie, mimo podejmowanych prób nadania tej dyscyplinie bardziej teologicznego charakteru i oparcia jej na eklezjologicznych podstawach, dominowało klerykalistyczne ujęcie, które koncentrowało się głównie na przygotowaniu duchownych do właściwego wypełniania ich duchowego urzędu. Opartej na powyższych założeniach teologii pastoralnej, której głównym przedstawicielem był Michael Benger, odmawiano charakteru nauki teologicznej, traktując ją jako zwyczajne przygotowanie do zawodu duchownego ${ }^{10}$. Powstałe na takim fundamencie widzenie duszpasterstwa najtrafniej oddawały podręcznikowe jego definicje, które kształtowały kościelną świadomość aż do połowy lat sześćdziesiątych dwudziestego wieku. Jedna z nich, pochodząca z 1919 r., określała duszpasterstwo w następujący sposób [pisownia oryginalna]: $W$ świetle źródet $z b a$ wienia pasterzowanie ma być postugiwaniem kapłańskiem $w$ celu przyswojenia wiernym owoców Chrystusowego odkupienia. Z pospolitej też nazwy duszpasterstwa wynika, że materyalnym przedmiotem działalności pasterskiej sa dusze ludzkie [...]. Pasterzowanie więc jest działaniem w Kościele, podjętem w tym celu, by przez Ducha św. zrodzić w duszy życie nadprzyrodzone [...]. Pasterzo-

${ }^{9}$ Por. H. Schuster: Die Geschichte der Pastoraltheologie W: Handbuch der Pastoraltheologie. Bd. 1. Freiburg im Br. 1970 s. 40-52.

${ }^{10}$ Por. M. Benger: Pastoraltheologie. Regensburg 1861. 
wanie przelewa na dusze dobra duchowe, dane Kościolowi przez Chrystusa i prowadzi te dusze do szczęścia wiecznego ${ }^{11}$.

Opublikowany przez Księgarnię św. Wojciecha Mały stownik teologiczny, w kolejnym wydaniu z 1960 r., zawierał określenie duszpasterstwa, stwierdzające, że jest to nazwa ogólna dla czynności papieża, biskupów i kapłanów, które wypływaja z urzędu pasterskiego Kościoła, a więc czynności mających na względzie zbawienie wiernych. Duszpasterstwo wyższe, zwiazane z władza prawodawcza i sądownicza spetnia papiez $i$ biskup, a duszpasterstwo zwane niższym wykonywane jest przez duchowieństwo podporzadkowane biskupom. Do obowiazków duszpasterskich należy: odprawianie Mszy św., udzielanie sakramentów św., głoszenie słowa Bożego, nauczanie prawd wiary, troska o potrzeby duchowe wiernych, a nawet materialne, w ramach dobroczynności chrześcijańskiej ${ }^{12}$.

Zasadniczy przełom w rozumieniu duszpasterstwa związany jest ze Soborem Watykańskim II, który pokreślił komunijny wymiar Kościoła. Pracom soboru towarzyszyła, niejako równolegle, refleksja podejmowana na terenie teologii pastoralnej, rozwijająca wcześniej rozpoczęte poszukiwania nad wypracowaniem eklezjologicznej koncepcji teologii pastoralnej i duszpasterstwa. Zgodnie z nią podmiotami działalności Kościoła, obejmującej jego pośrednictwo zbawcze, są wszyscy członkowie ludu Bożego, którzy przez chrzest zostali włączeni do wspólnoty Chrystusowej. Takimi podmiotami są również społeczności i organy Kościoła. Tak więc w swej strukturze Kościół charakteryzuje się wielością członków i różnorodnością funkcji spełnianych przez nich. Przedmiotem zaś jego działalności jest sam Kościól, czyli wspólnota zbawienia. Chrystus bowiem ustanawiając Kościół przekazał mu zespół środków w celu wypełnienia pośrednictwa zbawczego. Dzięki temu posiada on własne, immanentne siły, aby się budować i aktualizować. W Kościele nie ma zatem jakiegoś działania tranzytywnego, części aktywnej i pasywnej - lecz jest działanie zróżnicowane całości. Nawiązując do biblijnych obrazów, można by powiedzieć, że cały Kościół jest pasterzem i trzodą, szafującym i przyjmującym, jednym i całym ${ }^{13}$.

Wspomniane poszukiwania były kontynuowane później i zmierzały do pogłębienia pojęcia kościelnej komunii. Dokonywało się to w ramach dyskusji, której uczestnikami byli liczni teologowie, m.in. Karl Rahner, Heinz Schuster czy Norbert Greinacher. Jednakże zasadniczą rolę odegrał w niej Ferdinand Klostermann, głównie poprzez pogłębione studium na temat wspólnoty. Większość uczestników wspomnianej dyskusji dochodziła do sformułowania idei Kościoła-

${ }^{11}$ Ks. Dr P. C z a p l a: Ogólne zasady duszpasterstwa. Nakładem „Ateneum Kapłańskiego”. Włocławek 1919 s. 12-13.

${ }^{12}$ M. Kowalewski: Duszpasterstwo. W: Mały słownik teologiczny. Poznań-Warszawa-Lublin 1960 s. 105.

${ }^{13}$ Por. Por. F. B 1 a c h n i c k i: Teologia pastoralna ogólna. Cz. 1. Wstęp do teologii pastoralnej. Teologiczne zasady duszpasterstwa. Lublin 1970. 
wspólnoty opierając się na krytyce tradycyjnego ujmowania podmiotu duszpasterstwa, zacieśnionego do funkcji samych tylko kapłanów-pasterzy. Tymczasem Klostermann wyszedł od pytania o miejsce i znaczenie wspólnoty w Kościele. Odwołując się do pogłębionej analizy danych Objawienia doszedł do wniosku, że wspólnota jest centralnym miejscem $\mathrm{i}$ istotnym elementem urzeczywistniania się Kościoła. W swych rozważaniach poszedł tak daleko, że nie wahał się stwierdzić, iż Kościół z zasady ukazuje się światu przede wszystkim jako wspólnota, a jego obecność w świecie w sposób zasadniczy jest uzależniona od wcielenia się w konkretną wspólnotę ${ }^{14}$. Podkreślał, że powstanie Kościoła nie jest wtórnym procesem organizowania się pojedynczych osób, które przyjęły chrzest i bierzmowanie, ale jest procesem wnikania w konkretną wspólnotę człowieka, który w tajemnicy wiary i chrztu staje się członkiem Kościoła. Klostermann sięgał w tym wypadku do specyficznie chrześcijańskiego sensu pojęcia wspólnoty, wywodzącego się od nowotestamentowego terminu ekklesia, które odnajdywał w nauczaniu św. Pawła Apostoła, szczególnie w Pierwszym i Drugim Liście do Koryntian. Zwracał także uwagę, odwołując się do budowania różnych wspólnot, poprzez które dokonuje się aktualizacja Kościoła, że owo budowanie wspólnoty jest właściwym przedmiotem i zarazem podmiotem duszpasterstwa. W budowaniu wspólnoty biorą aktywny udział wszyscy jej członkowie, choć w różnym zakresie w i różny sposób, w zależności od powołania, charyzmatu, pełnionego urzędu czy święceń. Klostermann mówił wprost o wspólnocie jako zasadzie życia Kościoła (Prinzip Gemeinde) i równocześnie teologii pastoralnej rozumianej przez niego jako teologia życia Kościoła ${ }^{15}$.

Polski pastoralista, ks. prof. Franciszek Blachnicki, podkreślał, że dla rozumienia tej sprawy ważne jest przekonanie, iż urzeczywistnianie Kościoła jako »koinonii«, ze wszystkim, co wchodzi w istotna treść tego pojęcia, jest celem wszelkiego dziatania Kościoła. "Koinonia" jest również ostatecznym kryterium oceny adekwatności aktualnej postaci Kościoła lub jego aktualnego stanu oraz jego działania w odniesieniu do jego istoty oraz misji, zleconej mu przez Pana ${ }^{16}$. Podjął on próbę ujęcia teologii pastoralnej i duszpasterstwa, ukazując wspólnotę (communio) jako ich zasadę. Dokonał tego uzupełniając o elementy spekulatywne i dedukcyjne analizy Klostermanna, który sformułował zasadę wspólnoty, odwołując się głównie do fenomenologicznego opisu i analizy danych

\footnotetext{
${ }^{14}$ Refleksje te zawarte zostały w pracy - F. K l o s t e r m a n n: Prinzip Gemeinde. Gemeinde als Prinzip des kirchlichen Lebens und der Pastoraltheologie als der Theologie dieses Lebens. Wien 1965. Wiener Beiträge zur Theologie. Band XI. Dalsze rozwinięcie tematyki związanej z zagadnieniem wspólnoty znaleźć można w kolejnej pracy - F. Kl o s te r man n: Gemeinde Kirche der Zukunft. Thesen, Dienste, Modelle. Bd. 1-2. Freiburg Basel Wien 1974.

${ }^{15}$ Szerzej na ten temat - A. P r z y b e c k i: Budować wspólnotę, czy administrować? Pawłowa inspiracja dla polskiego duszpasterstwa. „Teologia Praktyczna. T. 10: 2009 s. 77-81.

${ }^{16}$ F. B 1 a c h n i c ki: Teologia pastoralna ogólna. Cz. 2. Eklezjologiczna dedukcja teologii pastoralnej. Lublin 1971 s. 447.
} 
wziętych ze źródeł Objawienia, a także danych dotyczących początków Kościoła. W związku z tym ks. Blachnicki określał duszpasterstwo jako działalność zbawczą Kościoła, która winna być sprawowana w duchu personalistycznym i uwzględniać wszystkie prawa życia osobowego, jakie znajdują się u podstaw procesu zbawczego, będącego dialogiem i spotkaniem. Ponieważ jednym z ważnych praw życia osoby jest możliwość realizowania się i rozwoju ku pełni we wspólnocie, stąd jej tworzenie jawi się jako konsekwencja i zarazem warunek rozwoju życia osoby. Prawidłowość ta - podkreślał - dotyczy również wymiaru nadprzyrodzonego istnienia osoby ludzkiej, odnajdywanego w Bożym planie zbawienia. Dlatego budowanie wspólnoty (communio) musi być zasadą duszpasterstwa. Jak podkreślał, ta wspólnota tworzona przez działalność duszpasterską jest wspólnotą z Ojcem przez Jezusa Chrystusa i w Duchu Świętym. Realizuje się w Kościele w powiązaniu $\mathrm{z}$ innymi ludźmi, objętymi także Bożym planem zbawienia, w określonym momencie historii i w konkretnej grupie społecznej. $Z$ tego m.in. powodu całą działalność Kościoła, czyli jego funkcje należy rozpatrywać $\mathrm{w}$ aspekcie społecznym, czyli jako sposoby urzeczywistniania się Kościoła-wspólnoty w konkretnych wspólnotach. Kościół zatem staje się obecny przez liturgię, w której manifestuje się jako wspólnota i znak ją urzeczywistniający. Aktualizuje się przez martyrię pojmowaną jako słowo przepowiadania ściśle powiązane $\mathrm{z}$ funkcja katechumenatu, odnawiającego wspólnotę Kościoła wprowadzaniem do jego wnętrza nowych pokoleń. I wreszcie urzeczywistnia się poprzez diakonię, która jest wyrazem miłości, stanowiącej istotny przejaw życia wspólnoty chrześcijańskiej i warunkującej jej wzrost. To właśnie dzięki aktualizacji tych funkcji budowana jest wspólnota - koinonia en Christo ${ }^{17}$.

W oparciu o takie widzenie duszpasterstwa, najczęściej definiowane jest ono dzisiaj jako zorganizowana działalność zbawcza Kościoła urzeczywistniajaca w stużbie człowieka zbawcze dzieło Chrystusa przez głoszenie słowa Bożego, liturgię, postugę pasterska i świadectwo życia chrześcijańskiego ${ }^{18}$.

\section{Duszpasterstwo czy troska pasterska?}

W odrębnym dokumencie Nadzwyczajny Synod Biskupów, zwołany przez Jana Pawła II w 1985 r. z okazji dwudziestej rocznicy zakończenia Vaticanum II, zwrócił uwagę, że głównym punktem nauki o Kościele, ukazanym przez Sobór Watykański II jest eklezjologia „komunii” (communio). Ojcowie Synodu mówią wprost: Eklezjologia ,komunii" (»communio «) jest idea centralna i podstawowa $w$ dokumentach Soboru. Pojęcie »Koinonia - communio«, oparte na Piśmie Świętym, cieszylo się w Kościele starożytnym i cieszy do dziś w Kościołach Wschodu wielka czcia. Stąd Sobór Watykański II uczynit wiele, aby Kościót byt

\footnotetext{
${ }^{17}$ Por. F. B 1 a c h n i c k i: Teologia pastoralna ogólna. Cz. 1, dz. cyt., s. 302-303, 348.

${ }^{18}$. R. K a m iń s k i, W. Pr z y g o d a: Duszpasterstwo, dz. cyt., s. 201.
} 
wyraźniej rozumiany jako „komunia” $i$ bardziej konkretnie jako „komunia” urzeczywistniany. W kolejnym akapicie tego dokumentu Synod formułuje pytanie: Co oznacza ogromnie bogate $w$ treść stowo »communio«? I odpowiada: Podstawowy sens odnosi sie do zjednoczenia z Bogiem przez Jezusa Chrystusa w Duchu Świętym. To zjednoczenie dokonuje się w Stowie Bożym i sakramentach (»Lumen gentium«, 11). »Komunia« z Ciałem Chrystusa w Eucharystii oznacza i sprawia, czyli buduje wewnętrzne zjednoczenie (»komunię") wszystkich wiernych w ciele Chrystusa, którym jest Kościót (por. 1 Kor 10, 16 n.) ${ }^{19}$.

Z kolei Jan Paweł II, na zakończenie Roku Jubileuszowego w Liście apostolskim Novo millennio ineunte, powiedział wprost: Czynić Kościót domem i szkoła komunii: oto wielkie wezwanie, jakie czeka nas w rozpoczynajacym sie tysiacleciu, jeśli chcemy pozostać wierni Bożemu zamysłowi, a jednocześnie odpowiedzieć na najgłębsze oczekiwania świata ${ }^{20}$.

Skoro zatem owo komunijne rozumienie Kościoła jest sprawą tak ważną, spróbujmy odpowiedzieć na pytanie, jak można je uwzględnić w pojęciach, które opisują jego aktywność duszpasterską?

Pewne sugestie znaleźć można w oficjalnych dokumentach Kościoła. Wydany w 1983 r. przez Jana Pawła II nowy Kodeks Prawa Kanonicznego raczej unika używania pojęcia cura animarum (troska o dusze, duszpasterstwo). Stosuje natomiast określenie cura pastoralis (troska pasterska). W definicji parafii wskazuje, że jest określona wspólnota wiernych, utworzona na sposób stały w Kościele partykularnym, nad która pasterska troske [cura pastoralis], pod władza biskupa diecezjalnego, powierza sie proboszczowi... (kan. 515 §1). Precyzując charakter posługi proboszcza, mówi, że jest on własnym pasterzem zleconej sobie parafii, podejmujacym pasterska troskę [cura pastorali] o powierzona mu wspólnotę. (kan. 519). Podobnie w kan. 527 §1: Kto jest promowany do podjęcia troski pasterskiej [curam pastoralem]w parafii, otrzymuje ja i obowiazany jest pasterzować od momentu jej objęcia w posiadanie. W innym miejscu, w tytule rozdziału pierwszego, poprzedzającego kan. 1063, który omawia zagadnienia związane z zawarciem małżeństwa, używa następującego określenia: Pasterska troska [De cura pastorali] i czynności poprzedzające zawarcie matżeństwa.

Podobnie w łacińskim (typicznym) wydaniu Katechizmu Kościoła katolickiego używane jest określenie cura pastoralis (troska pasterska), np. w punkcie

\footnotetext{
${ }^{19}$ Kościót kierowany przez stowo Boże sprawuje Tajemnice Chrystusa dla zbawienia świata. Relacja Końcowa z Nadzwyczajnego Synodu Biskupów. „Przegląd Katolicki”. R. 74: 1986 nr 4 pkt II, C, 1 .

${ }^{20} \mathrm{~J}$ a n P a w e 1 II: List apostolski Novo millennio ineunte. Libreria Editrice Vaticana 2001 n. 43a.
} 
2179, w którym mowa jest o parafii, zacytowano w oryginale wspomniany wcześniej kan. 515 §1 Kodeksu Prawa Kanonicznego.

Można sądzić na podstawie przytoczonych przykładów, że w oficjalnych dokumentach kościelnych proponuje się używanie określenia, które zrywa z tradycją pojęcia, mniej czy więcej wyraźnie nawiązującego do klerykalistycznej koncepcji duszpasterstwa i sugerującej, w sposób nieuprawniony, zawężenie przedmiotu działalności zbawczej Kościoła wyłącznie do ludzkiej duszy. Tymczasem działalność zbawcza obejmuje całego człowieka, tak w wymiarze indywidualnym jak i społecznym.

Warto też na koniec wskazać na inną możliwość bardziej adekwatnego wyrażania sensu, jaki zawiera w sobie aktualne rozumienie pojęcia duszpasterstwo. Wiele bowiem nieporozumień wynika z pewnych nieścisłości, które spotykamy w polskich przekładach oficjalnych tekstów kościelnych enuncjacji. Zbyt często nie zauważa się, że w większości języków zachodnich funkcjonują, tak jak np. w języku niemieckim, dwa nieco różne określenia-Seelsorge [duszpasterstwo] i Pastoral [pastoralna, np. działalność], które w większości wypadków thumaczy się u nas wyłącznie na polskie „duszpasterstwo”. Brakuje bowiem w języku polskim drugiego rzeczownika, który odpowiadałby owemu Pastoral. Tymczasem słowa te, choć podobne, posiadają jednak nieco inny odcień znaczeniowy. Owe subtelne różnice wyjaśniał kilkanaście lat temu Josef Müller, ówczesny profesor teologii pastoralnej na Uniwersytecie we Fryburgu (w Bryzgowii). $\mathrm{Z}$ jednej strony podkreślał zamienne używanie tych dwu pojęć w bieżącej praktyce, ponieważ określają one całościowo pole kościelnej aktywności, z drugiej wskazywał na istniejące między nimi różnice. W jego przekonaniu wyrażenie Seelsorge zawiera w sobie bardziej personalne odniesienie, „od osoby do osoby” („do wewnątrz” wspólnoty - ad intra), zaś Pastoral, przeciwne, rozszerza je i wymaga związania z całością kościelnego działania, szczególnie tego, które adresowane jest ad extra, tzn. do współczesnego świata jako całości (w tym sensie należy rozumieć tytuł soborowego dokumentu - „Konstytucja pastoralna [duszpasterska] o Kościele w świecie współczesnym Gaudium et spes" ${ }^{21}$. Wydaje się, że w obszarze tych pojęć jawią się pewne szanse bardziej precyzyjnego operowania określeniem „duszpasterstwo”, zwłaszcza że na co dzień, w większości wypadków bezrefleksyjnie, używa się obok pojęcia „duszpasterstwo” także drugie-,,działalność pastoralna”.

${ }^{21}$ J. Müller: Pastoraltheologie. Ein Handbuch für Studium und Seelsorge (Kapitel 1.2: Zur Unterscheidung der Begriffe "Pastoral" und ,Seelsorge“). Verlag Styria. Graz, Wien, Köln 1993 s. $15-16$. 